\title{
Africa and China Relation: The Basis of a Genuine Cooperation: An Interview with Prof. Dr. Lou Shizhou on a Possible Veritable Cooperation Between Africa and China
}

\author{
Jean GONONDO \\ Institute of Education Science, Zhejiang Normal University, 688 Yingbin Avenue, \\ Jinhua City, Zhejiang Province, 321004 China
}

\author{
Interviewee: Lou Shizhou (楼世洲) \\ Professor, Zhejiang Normal University (ZJNU), China.
}

Director of the Centre of African Education Studies at ZJNU, National Education Professional Degree Teaching Steering Committee, Ph.D. Candidates Supervisor. Professor Lou Shizhou is a former Vice President of Zhejiang Normal University. His main research fields include Education policy, Education History, Education in Africa. Interviewer: Jean Gonondo

Ph.D. Candidate, Zhejiang Normal University, China.

Keywords: Africa, China, Cooperation ideology.

Precision: [This interview took place on January $11^{\text {th }}, 2018$ at Zhejiang Normal University, China.]

Jean Gonondo: Professor, you have been in many countries not only in Africa, but also all over the world. Please, can you give us your opinion about the current international relations?

Lou Shizhou: Westerners are talking about an "Order" now, they are saying everyone should abide by this "Order", but the question is, who benefits the most from this "Order" in the trading system? The more developed the country is, the more favourable it is to benefit from it. Then in such a trading system, the rich will always be rich, and the poor will always be poor. This is what the West wants.

Jean Gonondo: Many developing countries know about this "Order" being established by the Westerners, and as such try to seek for solutions. China is one of these countries looking for the solutions to balance the international relations. What is China's contribution to the global international relations? What is China's ideology of cooperation?

Lou Shizhou: Now the developing countries with China at the top, have to break this "Order". This "Order" of the world cannot be the same, and shouldn't continue being like this. The entrance of China into the "Dance Hall" brings a new way of considering people and is contributing to reducing the huge disparities in the trade world. China wishes that there shouldn't be gaps between the rich countries and poor countries, we need to cooperate in a fair way, being all equal.

Jean Gonondo: All equal? Of course, this is our strong desire and hope, but how can we reach such a huge goal and mission? On what do we rely on to promote equality?

Lou Shizhou: What does China rely on to face developed countries? —-The market. For example, if powerful countries have a phone and they want to sell it, selling it to other countries will be faced by a smaller market, thereby reducing their profits. But, China has almost 1.4 billion people and the market is very huge. If powerful countries wish, they can sell their products to China, but they have to decrypt and decode the secret of production and then come to China to produce. If they do not decrypt and decode the secret of production, then we reject their products and won't buy from them.

I remember when Japanese wanted to sell us televisions, we asked them to come here to produce these televisions. Although they demanded a high price, we accepted to pay, because it did not only provide employment opportunities for the local population, but we also learned the techniques of production from them.

Jean Gonondo: How about African countries?

Lou Shizhou: What does Africa depend on? In addition to the labour force and youth, Africa has a lot of resources. Africa should set conditions to those who want its resources. For instance, Africa could say you need my resources, okay, but I'm not selling the resources to you, I'm going to transform them into finished products and sell them to you. In the past, Nigeria had a situation whereby the State sold oil and crude oil to the Westerners, and the Westerners transformed it into petrol and diesel and then sold it back to Nigerians. In such a situation, who is gaining the highest profits? It is the Westerners. African countries should set conditions for countries that need their resources; and one of these conditions should be that the resources must be refined in Africa, to ensure Africans' own common interest. In this way, African countries will have a part of the right to manufacture, increase employment and learn the techniques of production. After a while, Africans would be able to transform their resources themselves and then sell the finished products to other countries.

Another way to face the powerful countries is that African countries must unite. Because if Africa is not united, each country's individual power is too small to have a say in the larger market. But if East, West, Central, North and South African countries join together as a real integrated community, their power will be very 
significant to face the powerful countries and their conditions.

Another big challenge in Africa are the problems of infrastructure, transportation, communication and resource protection. If these problems are solved, there will be hope for Africa's Renaissance. If you have no good transportation conditions, how can you develop? You cannot melt into the world's big system. Now in China, there are high-speed trains everywhere, transportation is becoming very convenient and the economy is also growing up, the process of urbanization is developing so as the level of education is increasing.

Jean Gonondo: Professor Lou, you are saying that African countries must unite, and give orientation to their cooperation; you have been to some African countries like Senegal, Kenya etc. Please can you tell us the impression you have about African leaders?

Lou Shizhou: When I go to Africa, I feel that many African politicians have very good, broad and new political concepts to develop their country. They have some very good ideas, which have been taken or learned from the West. But they don't think about how to link and combine these "good ideas" with their own national realities, how to concretize and implement these ideas to the benefit of the local population. Therefore, as soon as they become leaders, the first thing they think about is to look for means to fill their own pockets, and then choose some group of people to occupy some key government positions. The "new-comers" start to criticize and scold the former occupants of the office, while the issues which they themselves criticize for still remain unresolved. I think that is the lack of a deep national attachment power. Where can these needed strength come from? The strength relies on the youth, the young educated people. Young educated people can find more opportunities and conditions to produce more results.

Jean Gonondo: Some time ago China was also poor like many African countries, but today China stands as a model not only for African countries, but also for Western developed countries. Do you think that African countries could positively surprise the world in the future?

Lou Shizhou: China's 40 years of reform, opening-up and development are very good and significant experiences for African countries. 40 years ago, China was very poor. But we have chosen the right direction and worked very hard to reach our goal.

I think African countries have to choose the right direction and they will be able to come up after 40 years, 30 years or even less. They must not be fooled by the so-called "Order" and "Democracy". Whose democracy? Who are the beneficiaries of that democracy? Someone gives you some money to vote for him, or encourages you to go to the streets to protest, is that democracy? In fact, that is not democracy. True democracy comes from the will of the individuals. In the United States, if you give someone some money to go to the street to protest, he won't accept it, because he has his own income, but in Africa it is not the same case. Why? Because most of them have low incomes. National interests should be the interests of everyone.

Jean Gonondo: What legal form of state would you recommend to African countries?

Lou Shizhou: Sometimes, centralization is not compulsively a bad thing and decentralization is not necessarily a good thing. I think in Africa, during this special stage in their development, a certain level of centralization is still needed. Having a national consensus is inevitable, all the decisions should be taken to propel the economic development of the country for the prosperity of all. We shouldn't be blinded by the so-called "democracy".

If China had not controlled the so-called "Democratic wave" movement when it appeared in 1989, there would have been a national unrest and trouble, till now; then people with the financial position would have used this chaotic period to take advantage of properties, and implement privatization. And we know that privatization does not produce wealth and advantage for all, but only for a few people. To a favorable extent, state-owned properties create a lot of advantages for everyone.

To be considered as a valuable system, democracy must live in every citizen's heart and become a kind of intrinsic value. If it doesn't come from our heart, if the State cannot control, if people do not have a "deep national thought" from the bottom of their heart, and if life is not improved, then that kind of democratic system will only appear like a mirage, because it is like a smoke shown to people. "Democracy" is used by some people just as an illusion. And a small group of people exploit this opportunity to reap the benefits for themselves.

Jean Gonondo: Then, why is democracy possible in the West?

Lou Shizhou: It is possible in the West because they have a deep culture, history and tradition with that system, but we don't have it. If we want to bring it and use it in our country, we must be well-informed to a certain level.

Now, we are talking about ruling the country based on law and democracy, but we are not giving the real example to our people. Democracy is possible only when it emerges consciously. But when the people do not have this consciousness, or do not know what democracy is used for, some group of people will just use it as a tool for their own benefits, and in this case it is more frightening. China had also faced this period of blindness and ignorance. That was during the Cultural Revolution, there was no rational heart. But today it's totally different.

So we shouldn't only base our judgment on talking, but more on doing. This is very important.

Jean Gonondo: Professor, you did a lot of researches on educational policy, history of education and especially education in Africa. Not forgetting that you are the Director of the Centre for African Education Studies at 
Zhejiang Normal University. What do you think about Education in Africa?

Lou Shizhou: When I went to Africa, I observed three things:

Firstly, the higher education system was built on the basis of the old system with an elite service. In some African countries, the university is free of charge: free tuition and they offer scholarships. It is very good to offer privileges to university students, but the system has a disadvantage. The State's financial resources cannot be expanded, higher education cannot be expanded too. In order to expand the higher education institutions, they rely only on the establishment of private universities. And we know that private universities are very expensive and only wealthy families can afford to enrol their children there, but financially poor people can't. So, there is a dilemma.

China abolished free university system and welfare system in 1985. I graduated in 1982, and at that period I enjoyed not only free tuition but also living expenses. But from 1985, the government began to cancel these privileges, and everyone had to pay his own tuition. From the individual perspectives, paying tuition fees could be certainly challenging, but from the perspectives of the whole country it is beneficial. The state can use the money derived from payment of tuition fees to expand the scale of higher education. Thus, many people could receive higher education. I think, higher education reforms must begin with tuition fees reform. But now, many African governments are afraid to implement such reforms, because students could maybe march on the streets to protest. I saw it in some African countries. Students went to the streets to express objection and disapproval, a few days later, teachers also went on strike claiming that their treatment is not fair and so on, but the fact is that the government has no money.

Secondly, another problem is that many universities do not have the professional design of the local service concept and goals. So, many students from higher education institutions can't find jobs after graduation, and then they become unemployed, and socially undesirable.

Thirdly, African countries should develop technical and vocational education as large as possible to learn skills and techniques. The government should aim at importing as few as possible products, and build as many factories as possible, then employ graduates from these technical and vocational institutions. This will solve a lot of problems. It will also increase the processing capacity of the local resources by using new technologies, rather than relying entirely on crude labour. African countries should strictly prohibit digging and sale of resources and raw materials. Resources must be transformed into finished products before being exported. Raw materials should be processed in Africa and local labours should be employed. By so doing, African countries will conserve resources on one hand, and increase employment on the other.

For the Renaissance of African countries, the expansion of technical and vocational education, the popularization of higher education and the universalization of basic education are crucial. 